\title{
ACTUAL CHANGES IN SYSTEM OF URBAN PLANNING IN POST-SOCIALIST CITY: THE CASE OF PRAGUE
}

\author{
Filip LANDA \\ Department of Civil Engineering, Faculty of Technology, Institute of Technology and Business in České \\ Budějovice, Okružní 10, 37001 České Budějovice, Czech Republic \\ E-mail:landa.filip@gmail.com
}

Received 30 April 2016; accepted 4 October 2016

\begin{abstract}
After the change of political system in Czechoslovakia (1989) came also a lot of social, economical and cultural changes. Today, all the Czech cities stay in front of the biggest change of city planning philosophy in last two decades. Prague, the capital city of Czech Republic, decided for a big institutional transition in 2012.

The municipality, in cooperation with Faculty of Architecture CTU in Prague, is preparing completely pioneering methodology for quality commissioning of land use plans and, in cooperation with the new Institute of Planning and Development, is preparing innovative system of city planning. There are new ordinances, laws, regulations, tourist trade strategies and many other documents. Prague, as one of the strongest regions in East-Central Europe, can be seen like a laboratory of current development of post-socialist city. The new methodology of Metropolitan Plan could be a key to success.
\end{abstract}

Keywords: democracy, post-socialist city, Prague, metropolitan plan, urban planning, city development, methodology, Velvet revolution, image of the city.

\section{Introduction}

Before The Second World War there was a big minority of German speakers in Czechoslovakia, who played an important role in cultural and architectural field. In 1939, before the start of World War II, Czechoslovakia had to commit big part of its borderland to Germany (Sudetenland). After the War, most of the Sudeten Germans were largely expelled - they had to leave their homes in Czech borderland. The region of Sudetenland was inhabited primarily by Czech speakers, who didn't have any roots there, so they didn't have any relationship to the land. This complicated relationship was also reflected by architecture. Architect Matěj Páral, the founder of online database of German architecture in Czechoslovakia, says: "We are able to destroy more easily what we don't know any thing about." (see Páral 2007).

In the year 1948 came so called Coup d'état (Czech coup) - in Communist historiography known as "Victorious February" - which meant the radical change of political system in Czechoslovakia. The whole country was ruled by the Communist Party of Czechoslovakia and belonged to the Eastern Bloc. In
1968, during so called Prague Spring, came invasion of Soviet army and other members of the Warsaw Pact to the Prague to halt the incoming reforms. The loss of roots of former inhabitants in borderland and the rise of communist ideology in Czechoslovakia with economic impacts on the architecture and urban planning led in today's situation (Hejl, M. \& Coll. 2014), when the quality of contemporary architecture and city development in the Czech Republic could not equal to the quality level of architecture in the First Czechoslovak Republic existed from 1918 to 1938.

The political authoritarianism, according to the previous history, was expressed also through the way of city planning. The modernist doctrine based on the Athens Charter had a huge impact on urban planning in Czechoslovakia. Modernist planners came with a social-engineering's concept of the separation of areas by functional zoning. Human life was splitted up to dwelling, work, recreation and transport (see Mumford 2000). This unnatural separation of activities is durable in Czech Republic until today, what is signified in traffic hold-ups between settlements, administrative complexes, shopping malls and real city centres with 
theatres and cafeterias. Suburban growth was halted during communist times by the state's central planning urbanization policies, which channeled investments to urban centers and high-rise housing estates erected at the edges of the city (Kohout, Tichý, Tittl, Doležalová 2016). Since the collapse of the communist regime, cities in Czechoslovakia have entered a period of dramatic transformation. One of the most important processes in the ensuing frenetic rearrangement of urban space has been the dispersal of urban functions beyond the edges of the compact city. Postsocialist metropolitan growth of Prague has been characterized by fragmented spatial patterns broadly associated with urban sprawl and its controversial environmental, economic and social consequences, supported by the outdated planning methods (Stanilov, Sýkora 2014).

\section{History of land-use planning in Prague}

The creation of a comprehensive regulatory plan for Prague was one of the main objectives of the first professional agency to deal with urbanism in Prague - the State Regulatory Commission in 1929. The commission did complete Schematic Regulatory and Building Plan for the Capital City of Prague. However, it was never approved because too many objections were raised by individuals and city districts.

After the end of the war, in the spring of 1945 the commission began to operate under the Czech name Planning Commission for the Capital City of Prague and its Environs. Its mission was first to carry out the post-war restoration of buildings. After the coup in February 1948 it was instructed by the Communist government to develop a master city plan that would meet the new political requirements. The commission's members mainly focussed on transport issues. Yet this plan was never adopted either, and the Planning Commission was abolished when the administrative regions were established in 1949, and urban planning tasks were taken on by a department of the same name in the Central National Committee. The draft Master City Plan, which was intended to transform Prague into a socialist city, was approved in the 1960's (Borovička, Hrůza, 1983). The Prague City Development Plan Office also earned its place in the history of Prague because the State Institute for Reconstruction of Historical Towns and Buildings commissioned it to carry out a historical survey of the buildings of the centre of Prague. This is still an invaluable resource for research on the city's architectural development.

After 1989 the Office of the Chief Architect of Prague was seen by the public as a product of the socialist system. In 1994 it was thus divided into two organisations: the City Development Authority Prague
(ÚRM), responsible for developing the city plan, and the Spatial Planning Section for Prague City Hall, which issued zoning decisions under delegated powers. The first post-revolution master plan for Prague, referred to as the Land Use Plan for the Capital City of Prague, was approved in 1999. To date, up to 3000 amendments have been proposed for it. Finally, the urban development in the city of Prague is now coordinated by this land use plan. In view of some authors (Stanilov, Sýkora 2014) are the main principles of this plan maintaining a compact city structure and concentrating new development in areas with good accessibility by public transport. But in opinion of another authors (Hnilička 2012; Koucký 2006), the current land use plan allows very broad extension of build-up areas to the landscape. After detailed research of relevant documentation (Geoportal Praha 2013) is this also the opinion of author of this paper.

The problem is that the political landscape of metropolitan Prague is extremely fragmented. The capital city, which is both a city and a region, is subdivided administratively into 57 districts that are subordinated to the city government. Prague is surrounded by the Central Bohemian region, which is comprised of hundreds of administratively independent municipalities which do not share the same priorities and whose interests are often contradictory. A common strategy for Prague and its surrounding region is currently missing.

A new land use plan for the city of Prague was under preparation since 2007 and its draft version was approved in 2009. The new plan was conceived in accordance with the principles of sustainable development but it was still struggling with the same problems like previous plan.

There are more reasons for a huge exploitation of landscape by built-up areas in both planning documents from 1999 and 2009. First of all, there are complicated ownerships of land. The main goal and the first political priority of the postsocialist transition governments was the radical restructuring of the balance between the public and private realms (Stanilov, Sýkora 2014). The City privatized most of its land in so called "wild '90s". On these lands is now difficult to apply regulatory plans (see chap. Scales of Plan). The next problem is also a wrong coordination between existing land use plan and so called Principles of Territorial Development, which is superior and obligatory documentation for whole region. The last plan covering both Prague and the Central Bohemian region was adopted back in 1976.

The old concept of land use plan from 2009 had already over the 2000 amendmends and more than 16500 observations from public in 2011. The new 
government of City of Prague had seen that the situation is already unbearable and it is time to start to think about the City another way, otherwise Prague would start to decay. The efforts to finalize the new land use plan ceased in 2011, after a change in city government. The new administration blocked the adoption of the earlier draft plan and in 2012 established a wide consultation body to guide the development of a new version of the plan. The Prague City Council decided for commissioning of completely new land use plan, named as the Metropolitan Plan. This step represented the new vision of future Prague, which finally started to be discussed in more democratic processes.

\section{New paradigm: safety, communication, representation}

It seems that technology of urban planning reduced into "zoning plans" does not lead to the creation of good environment anymore. In 1989, after the change of political system in Czechoslovakia, came a lot of social, economical and cultural changes, which led to the need of turn-over of whole paradigm of city planning. But the executive and social processes were not prepared and they were unable to react so quickly. For example - Dantzig and Saaty considers already in 1973, that the concept of compact city is more advantageous than the modernistic vision of the city. The composition of most of the Czech cities lost their idea during the modernistic era of urban planning. The vision of a city was often built only from technical parameters, e.g. a traffic connection or coefficient of illumination. However, if the city doesn't have a vision, neither it doesn't have a figure. The main goal of the new urban planning system in Prague is a change of whole modernist paradigm. Famous Czech urban designer Jan Jehlík says, that dwelling, work and recreation (following Athens Charter) are not the basic functions of the city. Functions of settlement depend on relations between needs of inhabitants and manifestation of mental environment. Needs as a stabile factor, manifestations as a dynamic factor. So the basic functions of the city are different. Jehlík call them as a safety, a communication and a representation, while safety is not provided by the security, communication is not provided by the transfer and representation is not provided by promotion or marketing (Jehlík, Plos 2015; for more see Veselý 2004) .

The City is not a system, but an organism. Infrastructure has to be a part of rationality but it has to be coordinated with a whole on the basis of sense as well. And sense is an art which should be part of architecture itself. The architects included by the inefficient paragraphs of law, rules, ordinances and quotas are not able to create a City. And the City included by the financial limits and particular interests is not able to change rigid rules.

\section{Actual changes in Prague}

Prague (Praha) is the capital and largest city of the Czech Republic, also the fourteenth-largest city in the EU. It is also the historical capital of Bohemia. Situated in the north-west of the country on the Vltava River, the city is home to about 1.24 million people, while its larger urban zone is estimated to have a population of nearly 2 million.

Nowadays, Prague stays in front of the biggest change of urban planning and city development philosophy in last two decades. In my paper I start to call this change "velvet revolution" following the name of Czech non-violent transition of power from communist government to democracy. 25 years after this conversion finally starts also the transformation of strategy documents and urban planning processes.

\section{Office of Metropolitan Plan}

In 2013 the City Development Authority Prague (ÚRM) was transformed into the Prague Institute of Planning and Development (IPR). A name change should be a sign for further changes, shift of paradigm in approach to the City. The aim is to restore Prague to its place among the most advanced European capitals. New conceptual agencies were established - the Metropolitan Plan Office (MPO) and the Public Space Office. Their common objective is to return an emphasis on the quality of life to urban development. Highquality urban planning and governance requires clear and open communication and cooperation with the city's districts, the professional and the general public and other stakeholders. Because of this, the organisation of seminars and workshops for city districts and the organisation of exhibitions, discussions and lectures for the public are an integral part of IPR Prague activities.

The team led by architect Roman Koucký was chosen to prepare a new Land Use Plan for the city of Prague, named as "Metropolitan plan" (MP). Metropolitan Plan Office consists of experienced specialists, mostly architects and city planners, who have completed dozens of masterplans and got many awards, but there are also architects from the youngest generation, who gained valuable professional experience abroad.

The genesis of MP is open to public discussion however knowledge and the data grabbed by the previous institution are applied. The very new situation was born. The MPO cause that the topics such as landscape, city planning, quality of life, public space become se- 
rious topics in public discussion and influenced electoral promises of political parties. Finally city and architecture are really big issues. The new focus of city administration and public generally is very important. People are now interested in the care of their city more actively than before.

The Prague Building Standards (PSP) were formulated in parallel with the processing task of MP. PSP are entirely necessary for the MP and its new concept. Integral system of regulation is crucial for unification of concepts and new planning tools. Besides of MP the Prague Public Space Design Manual and the Conception of Prague Riversides were formulated as well as Management Plan of UNESCO Heritage Site is now discussed.

\section{Methodology of Metropolitan Plan}

The work on a completely new methodology of Metropolitan plan started in 2012. The name "Metropolitan" was used because city of Prague has wrongly defined administrative boundary - city is influenced and has an impact to much larger area. It caused chaotic situation influenced by the different administrative management and the lack of communication, bad for both of partners: City of Prague and surrounding Central Bohemian region. Therefore one of the aims of the MP is Plan of Wider Relations which should substitute the old Principles of Territorial Development. At least this document should be radically updated. Although the new Metropolitan Plan is not set to be completed until 2020, its methodology and the concept for its future form were already presented in spring 2014.

\section{Bases of the plan}

What the ideal methodology of MP for the capital city should be? How to keep and develop the category of "beauty" by rational processes of directive and restrictive legislation applied by bureaucratic practice? How to plan when the change is faster than the notation of this change? There is a surprisingly simple solution.

The first starting point is the effort to replace instruments of "function" and "zone" by requirement to define composition of the city and requirement of "beauty". It is necessary to reject dominant role of traffic engineers in city planning which causes many devastated territories. New approach should be based on the old-new bases, in what the "sense" is included, approach where the emotional and rational components are apoise.

Second necessity is a reconstruction of existing and planning of new public spaces as livable and memorable locations. Places with "humans scale" (Gehl 2006
[1971]). The key is the "image of the place", resulting quality, quality of space where we have to live, not the amount of the technical standards. Infrastructure is a necessary condition for the functioning of a locality, but is primarily a service, not crucial element. Architecture should not be understood as a technical field.

Third base is restriction of the senseless regulations and restrictions and vice versa promoting the emergence of correct city-forming projects.

\section{City boundary and "localities"}

Prague needs a very actual plan, which will reflect diversity and versatility of today's world. It is evident that the old system of city planning is unable to do that. Modernism solved all the unknowns and so deleted real life from cities. Today, against modernistic "everything will be exactly like this" comes empiric course when everybody has right for exceptions and individuality. The land use plan from 1999, which is still valid in Prague, is divided by these two tensions. It sees Prague as a homogeneous surface where is a lot of normative regulations needed and it is seen more as a regulative "handbook" than the "coordination of development". The result is thousands of changes and additions to the plan which are always potentially corruptive.

The new Metropolitan Plan doesn't include any directive methods of planning, so enables to realize also events and occasions that we are not able to predict at now. The question is, how to find the right dimension of liberty and abstraction. The flexible Metropolitan Plan find this dimension very obviously because the complexity of whole city is described by characters of 750 different localities. This method is not only instrument of regulation but also intelligible way how to see the City as a whole.

Locality is area integrated and defined by urban character. These areas should reflect not only unique current situation but also the future. By this way should be returned a clear organization and stratification of the city: center, compact city and periphery (Fig. 1). Is much more stable to formulate the spatial structure of the city by this way, than divide a city by using function zones which can change over time.

Localities are defined by its position in the city, the prevailing character of built-up areas and landscape, and the cultural and economic conditions. The new plan aims to support the urban character of the various localities, i.e., different regulations will apply to different localities. These regulations will help to prevent the development of solitary high-rises in inappropriate locations, such as residential areas. Regulations setting building height limits across Prague will also help to maintain its character. 

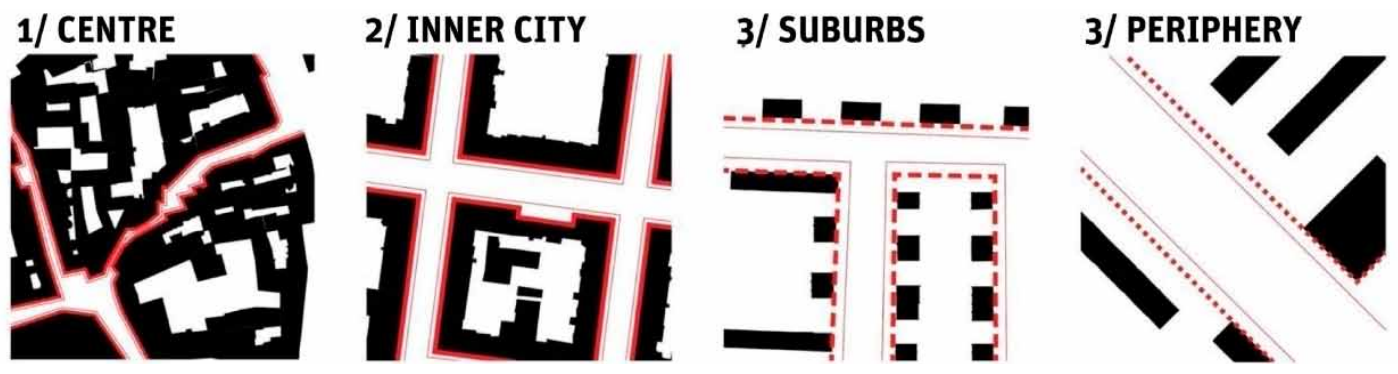

Fig. 1. Localities with different character - relation between streetline and building line

Source: IPR Praha, 2014

Character is a set of essential properties. Character of the buildings consists of the set of essential facts generated by the arrangement of the buildings (mainly location, intensity and quality of build-up area and range of stability), their manifestation, relations and binds in the context of urban and landscape structure: Centre (Historical downtown), Inner City (Block structure), Suburb (Garden City, Enclosed area amenities, Postwar settlements, Mixed areas), Periphery (Modernistic settlements, Production areas, Solitaires, Residential complexes, Sport facilities, Settlements for gardening, Fragmented system, Village).

Conclusion: The first purpose of MP is stopping of the uncontrolled expansion of developments into fields by defining clear borders between the city and the countryside. The next cornerstone of the MP is searching a clear and understandable concept, especially understandable composition of the city. It is no longer just about the technical parameters - coefficients and limits - but also about spatial composition and urban structure. The main reason for establishing of new term "locality" was the need to build and compose a city of the different parts than the "functional zones".

Identification aspects of the structure of build-up area for the use of Metropolitan plan are:

- perception of boundaries between public and private in terms of pedestrian;

- relation between streetline and building line;

- concept of mobility of people and goods in connection with ground floor;

- scale and typology of architecture.

\section{Rules of plan}

Rules of plan contains four basic elements:

(1) Rule of the first line - its bounds development;

(2) Rule of designing and tracing beautiful public spaces;

(3) Rule for a volume and the composition height of the city;

(4) Rule for proper timing, phasing of each step of the proposed development (Hrdlička, Koucký, Dvorská 2014).
Rule of the first line - its bounds development

It is important to define the boundary of build-upable areas, the indicator of economical, but also ecological size of the city. This is related with basic division of the city: the individual localities with degrees of usability, which will be defined for development or like unbuilt-able areas.

Places without possibility of development are important because of forming composition and character of landscape in which the city is located, and also landscape, which is a part of. Main reason is return of the form of the build and also un-built environment, as well as return of the necessary urban density to the "city" and liberation of landscape.

Rule of designing and tracing beautiful public spaces

Defines a network of public spaces, which helps to create the image of the city. On the public spaces are situated public buildings. Its character and composition also creates the city's image and must therefore be defined by plan.

Rule for a volume and the composition height of the City

The city have to define its composition not only in $2 \mathrm{D}$ plan, but also in $3 \mathrm{D}$ - by determining height levels and by determining old and new dominants. The third dimension is an integral part of the topography and the historical development of urban structure. The third dimension is also indicator of economical and cultural potential in different parts of the city.

Rule for proper timing, phasing of each step of the proposed development

The time dimension of the plan is given by defining priorities. The Metropolitan plan should define (along with other strategic documents) priorities, especially public investments, which will determine the development of the individual localities and therefore naturally and gradually brings further investments.

\section{Scales of plan}

Scale 1:25.000 is the upper level of the new Metropolitan plan. The Metropolitan plan provides 
mainly land use and defines the boundary between the landscape and the city. Sets the overall composition and shaping the image of the city. Defines polygon of public spaces and describe their formation and linking. It also provides key infrastructure routes and overall strategy for its implementation.

Scale 1:5.000 is lower level of the Metropolitan plan, specified in particular urban structure, layout and character and form of public spaces. It also defines the street and building lines for single perimeter blocks and the required infrastructure in detail.

Scale 1:1.000 is regulatory plan that will be prepared for localities that deserve special attention. It is detailed plan of public space and/or buildings, determine their specific solution/positions with other details like an installation of city furniture, landscaping, parterre etc. (Hrdlička, Koucký, Dvorská 2014) (Fig. 2).

The main problem of lower scales of Metropolitan Plan is an accordance to the actual Czech legislation. If the City is not an owner of the land, it is quite impossible to negotiate and certify regulatory plans. The cooperation between landlords and municipality is needed, otherwise it is impossible to conclude and make decisions. Historically it was very big mistake to sell most of the brownfields to private developers before the regulatory plans were made. Making of regulatory plans is also very expensive for local governments. The only way how to work out this situation is buyout of land by Prague Municipality - but it is expensive too.

\section{Ten basic theses of metropolitan plan}

\section{Implosion of architecture}

Prague doesn't have a sufficient density of built-up areas neither of actions and activities. There is a need to stop the extension of the city into the landscape and to activate its inner potential. To concentrate energy into the city centre. The development has to be perceived as an improvement of estates, not as a large expansion. The Metropolitan Plan places priorities on promoting brownfield redevelopment rather than development of greenfield sites.

\section{Historical town}

Prague has a deep and great history. The city was developed as a composed poly-structure, connected by Royal Route from east to west. The New Town of Prague was founded on the magic geometric system. For the future is very important to save not only these composing principles, but also to revive them and use them for the next development of city image. Especial property of Prague is also the heterogeneity and stratification. There is a need to support and fill in the middle of Prague by quality contemporary buildings and activities in them.

\section{Modernistic town}

Historic center is surrounded by necklace of modernistic settlements. Even these localities are an integral part of the history and present-day image of the city. It is necessary to search for a new quality of peripherals, which are today indispensable for the city. Most modernistic settlements remained unfinished composition. In this free urban structure is needed to define public space including parks.

Parks

Dramatic morphology is promoted by many city parks and "composed green". Also parks are architecture tasks and it is necessary to establish the new or existing places to a quality parks. It is also necessary to interconnect the parks and multiply their composition. Create a "green infrastructure". Parks are an inner recreational potential of the city.

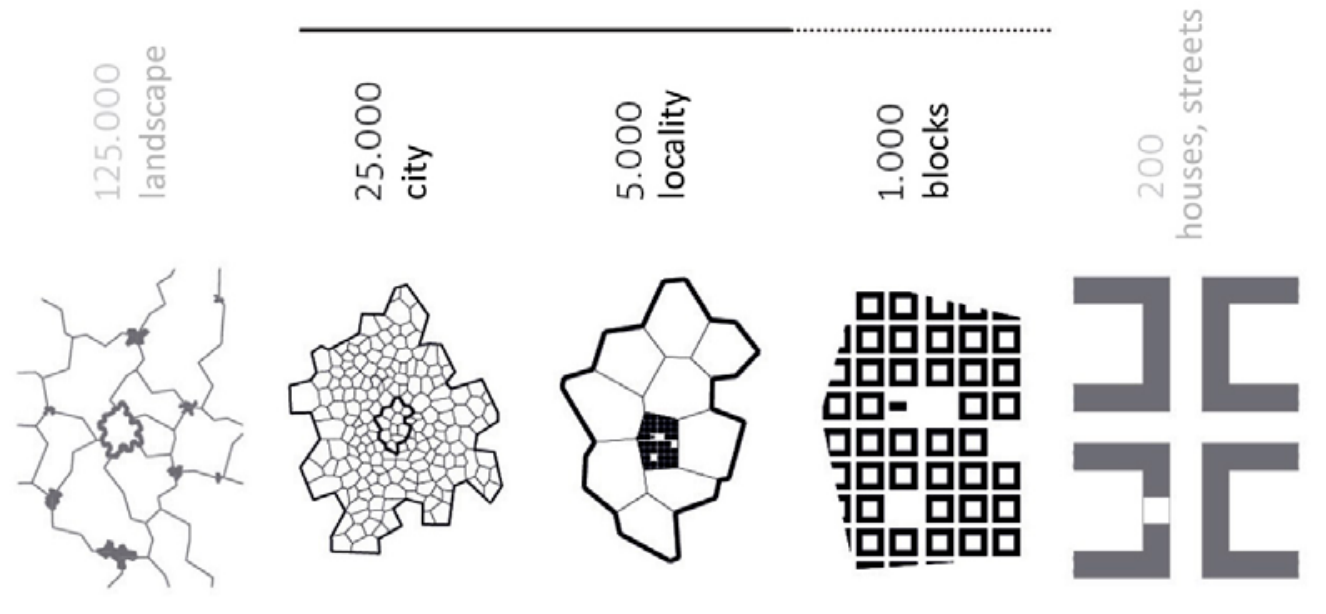

Fig. 2. Scales of the Metropolitan plan

Source: IPR Praha, 2014 


\section{River Vltava}

Landscaping for the city is always determining. The river has created a space of future city and till today presents the main axis of Prague. Vltava is a key public space. Together with its tributaries also determines the composition of parks and creates an overall image of the city.

\section{Green belt and landscape}

The "green belt" is in the European context simply understandable term. Nowadays, in the Czech Republic, this term gets into awareness. Detachment of the city and agglomeration is an important composition step. It must be clear where is inside and where is outside. Landscape stripe is seen as a boundary between city and countryside.

\section{Height regulation and the potential}

Prague is called "hundred-spires". But when was the last tower built? Man tried to build into the height for all history. Why now it should be otherwise? On the other hand, Prague obviously needs compositional height regulation to anticipate the erection of surprisingly high solitaire anywhere. The starting point is "positive height regulation", recommendation where to direct an energy.

\section{New bridges and connections (anastomosis)}

If the river Vltava is the middle of Prague, then it doesn't have to be a barrier. It should be a connection item of the city. Therefore is necessary to perceive both riversides and its islands as a complex unit, which relates to the city centre and to the city fringe as well. Prague needs the new bridges which will connect not only the riversides, but they will also prolong the streets, connect long-distance points and will make possible to overspread the dense traffic in the city centre. Current bridges in Prague have very long tradition and their future will be very important.

\section{Main avenues}

The image of the city is based on the structure of streets and squares. Today is important to strenghten current squares and local avenues and also to define new city avenues (seen from metropolitan scale). The new boulevards for Prague of 21th century should be bordered by alive and open parterre. Everything inside should be connected with neighborhood. It should be not only transport corridor, but it should become an important public space. Crucial crossing will be the node of historical north-east highway and new conceived North Diameter. This longest entire axis from east to west will connect all the important parts of the city and both Prague airports.

\section{Transformation vs. Development}

It is impossible to stop the development of city. But we can stop its extension. Prague has a lot of free areas inside the city. It is only necessary to fill in this places and concentrate the energy. That we can do by transformation of brownfields. So we will define the new boundary of city and there will be not a need to overpass them in perspective of whole 21th century.

\section{Tetractys}

The tetractys shows ten elementary theses to the city of Prague and their mutual interconnections. It is a triangular figure consisting of ten points arranged in four rows: one, two, three, and four points in each row, which is the geometrical representation of the fourth triangular number. Inspired by Pythagoreans is the tetractys applied on 10 theses of Metropolitan plan. In this system we can find a hierarchy of all topics and its logical clustering. By the diversity of clustering and diffusion of different layers along the axis we can get the basic message, so called "spirit of Metropolitan plan" (Fig. 3).

\section{Conclusion}

What is now happening in Prague is changing attitude to the City. It is exactly what was required by professionals many years. There is a need of applications of contemporary urban development trends, approaches and rules based mostly on the concept of compact city, sustainable mobility and limitation of suburbanization. New Metropolitan Plan and also Prague Building Standards take this topics into account and provides simpler legislative rules.

But now, in 2016, after the dynamic changes in political situation of Prague City Council is coming new threat, that the all effort will be canceled. The participation process showed all the shortcomings and complications of early democracy. A lot of stakeholders is not able to understand to the big abstraction of MP and comes with typical examples of NIMBY ("not in my back yard"). Sometimes the public debate shows contradictory conclusion - "we don't want suburbs (industrial and residential), but we don't want any new building in the inner city although it should be located in deprived 'green' areas".

The lower level of the plan (scale 1:5000 and 1:1000) will be applied only for some chosen localities and it is still not ready. The question is, if the new plan, without more detailed drawings, will be sufficient for decision making by local building authorities. Also the content discrepancy of Metropolitan Plan with the Principles of Territorial Development is criticised. There was some aspiration to update this superior doc- 


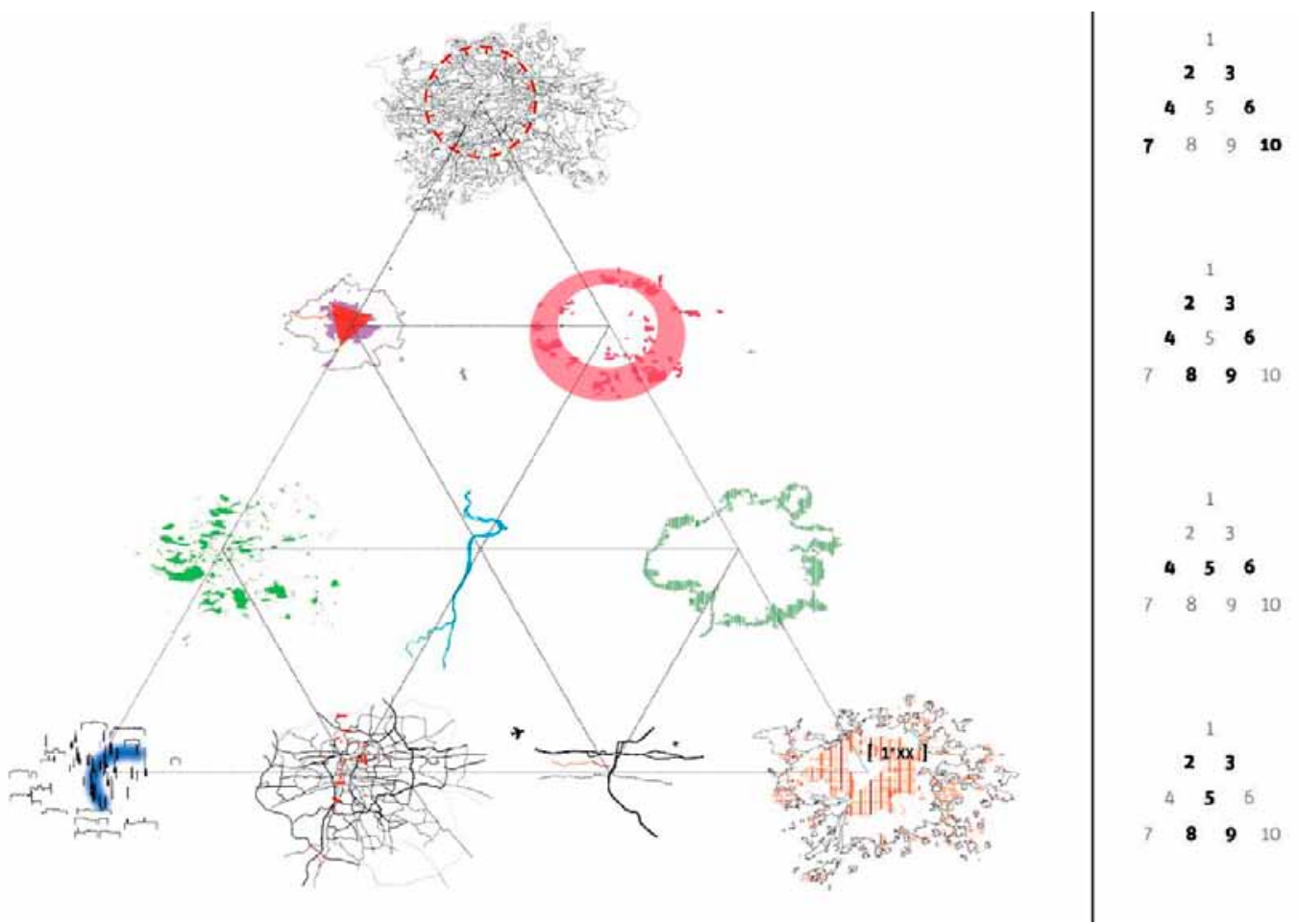

Fig. 3. System of tetractys - ten elementary theses to the city of Prague and their mutual interconnections Source: IPR Praha, 2014

umentation but it was disallowed by bustling political changes. The interventions of politics to the plan were very strong and exceeded all the competences given by electoral term.

These all problems, which are mainly caused by politics (not by architects working on the plan), led to the dismissal of director of the Prague Institute of Planning and Development Petr Hlaváček, who was elected in the spring of 2015, although he has been emphasizing increased public participation and intensified communication between IPR Prague, the city districts and the town hall. Withdrawal of Mr. Hlaváček was followed also by main architect of MP Roman Koucký and his team. Today there is nobody to continue on important works. So the future of city planning system of Prague is very uncertain.

\section{References:}

Borovička, B.; Hrůza J. 1983. Praha. 1000 let stavby města. Prague: Panorama.

Dantzig, G.; Saaty, T. L. 1973. Compact city: a plan for a livable urban environment. San Francisco: W. H. Freeman \& Co.

Gehl, J. 2006 [1971]. Life between buildings: using public space. Copenhagen: Danish Architectural Press.

Geoportal Praha. 2013. Map applications [online], [cited 30 April 2016]. Available from Internet: http://www.geoportalpraha.cz/en/map-applications\#.WBz0gfnhDDd

Hejl, M. \& Coll. 2014. 2 x 100 mil. m2. KOLMO.eu, Prague.

Hnilička, P. 2012. Sídelní kaše. Praha: HOST.
Hrdlička, P.; Koucký, R.; Dvorská, N. (Eds.) 2014. Koncept odůvodnění metropolitního plánu. IPR/SPM/KMP, Praha.

Jehlík, J.; Plos, J. (Eds.) 2015. Metodika zadávání územních plánů. CTU in Prague, Faculty of Architecture, Praha.

Kohout, M.; Tichý, D.; Tittl, F.; Doležalová, Š. 2016. Sídliště, jak dál? CTU in Prague, Faculty of Architecture, Praha.

Koucký, R. 2006. Elementární urbanismus. Praha: Zlatý řez.

Mumford, E. 2000. The CIAM discourse on urbanism, 19281960. Cambridge, Mass: The MIT Press.

Páral, M. 2007. O projektu [online], [cited 30 April 2016]. UstiAussig.net, Architektura na severu Čech. Available from Internet: http://usti-aussig.net/clanky/cist/nazev/4-o-projektu

Stanilov, K.; Sýkora, L. (Eds.) 2014. Confronting suburbanization. Urban decentralization in Postsocialist Central and Eastern Europe. Chichester: Wiley Blackwell.

Veselý, D. 2004. Architecture in the age of divided representation: the question of creativity in the shadow of production. Cambridge, Mass: The MIT Press.

\section{FILIP LANDA}

is architect and urban designer, managing editor of ERA21 architectural magazine. He studied Faculty of Arts and Architecture TU in Liberec, Czech Republic, now is studying PhD at Faculty of Architecture CTU in Prague. He also studied in Gent, Belgium and worked as an architect in Delft, the Netherlands and San Francisco, the U.S. Cooperation with Sféra Design Studio in Prague and teaching at Department of Civil Engineering at The Institute of Technology and Business in České Budějovice. Co-founder and coordinator of platforms focusing on regional architecture liberec-reichenberg.net and litomerice-leitmeritz.net. 